\title{
ILLICIT TRADE AND HOFSTEDE'S CULTURAL DIMENSIONS
}

\author{
Cassandra E. DiRienzo ${ }^{1}$, Jayoti Das ${ }^{2}$ \\ ${ }^{1}$ Elon University, Elon, USA, cdirienzo@elon.edu \\ ${ }^{2}$ Elon University, Elon, USA, dastina@elon.edu
}

\begin{abstract}
Research purpose. Growth of illicit trade has markedly increased and caused damage to a multitude of economic, socio-economic and environmental outcomes. The purpose of this paper is to examine the impact of Hofstede's country cultural dimensions on the attitudes towards illicit trade and the political will to counter the crime across countries.

Design/Methodology/Approach. The 2018 Global Illicit Trade index published by the Economics Intelligence Unit for 62 countries is empirically analysed. Six hypotheses are built and tested across Hofstede's six cultural dimensions.

Findings. The results indicate that countries that are culturally more individualistic, have greater uncertainty avoidance and have a stronger long-term orientation have a stronger structural capacity to protect against illicit trade on average.

Originality/Value/Practical implications. In reference to originality, the paper adds to the scarce research on the fight against global illicit trade and empirically explores the role that culture plays in driving the attitudes towards illicit trade and the political will to fight the crime. In reference to practical implications, anti-illicit policy initiatives are likely to be more challenging in collectivist countries with lower uncertainty avoidance and a shortterm orientation. Policymakers need to tailor their anti-illicit trade efforts in these countries as these societies will not likely place the same value on countering illicit trade as the countries that are culturally more individualistic, have greater uncertainty avoidance and have a strong long-term orientation.
\end{abstract}

Keywords: Illicit Trade; Culture; Corruption; Global Illicit Trade Environment Index

JEL codes: O57; I31

\section{Introduction}

Illicit trade has existed since ancient times, but over the last three decades, the growth of illicit trade has markedly increased. Given its clandestine nature, precise measures of the extent of illicit trade are challenging to obtain; however, the illegal economy has been estimated to be between $8 \%$ and $15 \%$ of the world's gross domestic product (GDP; Mashiri \& Sebele-Mpofu, 2015). As Shelley (2018,pg. 2) describes, '(o)ld forms of illicit trade persist, but the newest forms of illicit trade tied to computers and social media, operate as if on steroids'. The advancements in technology and the cyber arena have opened new sectors of illicit trade and these sectors are growing at an alarming rate. In 2017, an estimated $\$ 5$ billion was lost to ransomware and an estimated $\$ 15.4$ billion was lost to identity theft (Shelley, 2018). This raises questions as to governments' preparedness, capabilities and political will to combat illicit trade.

Recently, The Economist Intelligence Unit (EIU), commissioned by the Transnational Alliance to Combat Illicit Trade, created The Global Illicit Trade Environment (GITE) index. The GITE index measures the enabling environment for illicit trade that economies create through both action and inaction across the four categories of government policy, supply and demand, transparency and trade and the customs environment (EIU, 2018). In short, the index is designed to capture the ease of illicit trade in 84 countries. One of the primary factors facilitating illicit trade identified in the literature is corruption, as corrupt officials enable the exchange of a variety of illicit goods from cultural artefacts to 
human trafficking victims (Mashiri \& Sebele-Mpofu, 2015; Shelley, 2018; Fisman and Wei, 2009; Basu, 2014). Corruption along with measures of cybersecurity preparedness, intellectual property protection, tax burdens, international reporting, customs clearance and inspections, among a host of other quantitative factors designed to measure the illicit trade environment, are accounted for in the GITE index.

This study takes one step back and asks the question, what makes a country more (or less inclined) to dedicate resources to counter illicit trade? What are the factors that drive the political will to counter illicit trade? We argue that culture, as measured by Hofstede's six cultural dimensions, plays a significant role in driving the attitudes towards illicit trade and the political will to fight the crime. Before the theoretical arguments for the hypothesised relationship between Hofstede's cultural dimensions and illicit trade are presented, the following section offers a background and literature review of illicit trade and its relationship with culture.

\section{Literature review}

\section{What is Illicit Trade?}

Before a theoretical argument can be made linking culture to the illicit trade environment, it is important to first clearly define what is meant by illicit trade. As Shelley (2018) describes, illicit trade is much broader in scope than illegal trade. The Organisation for Economic Co-operation and Development OECD (2016) states that defining illicit trade is challenging as countries, and even regions within the same country, do not always agree on what goods can be legally traded. Nonetheless, the OEDC (2016) describes illicit trade as trade in '...goods and services that are deemed illegal as they threaten communities and societies as a whole'. The World Health Organization (2003) offers a more comprehensive definition of illicit trade as '... any practice or conduct prohibited by law and which relates to production, shipment, receipt, possession, distribution, sale or purchase including any practice or conduct intended to facilitate such activity.' There is not a single marketplace for illicit trade, since it can be conducted in the physical market, the virtual market or a mix of the two markets where stolen goods are sold on sites such as Amazon and eBay (Shelley, 2018).

The kinds of goods and services transacted through illicit trade are extensive. In terms of fish and wildlife, illicit trade involves overfishing and the poaching and overhunting of endangered species, including the rhino horn trade, which is threatening the extinction of the species (Mashiri \& SebeleMpofu, 2015; Shelley, 2018; Basu, 2014; OEDC, 2016). In the environmental sector, illicit trade includes the dumping of toxic waste, illegal harvest of timber, illicit carbon trade, illicit pesticides and counterfeit seeds (Mashiri \& Sebele-Mpofu, 2015; Shelley, 2018). In the goods sector, illicit trade involves the exchange of counterfeit or illegal pharmaceutical drugs, tobacco, alcohol, narcotics, currency, automotive parts, weapons and food, as well as stolen antiquities and cultural artefacts (OEDC, 2016; Shelley, 2018; Simmers and Schaefer, 2015; Stumpf and Chaudhry, 2010; Staake et al., 2009; Mashiri \& Sebele-Mpofu, 2015; Joossens et al, 2010; Fisman and Wei, 2009; Brodie, 2003; Basu, 2014). In the cyber sector, illicit trade includes the many forms of ransomware and identity theft (Shelley, 2018). Finally, and essentially by definition, illicit trade includes the sale of human trafficked victims for sexual and/or labour exploitation (OEDC, 2015; Shelley, 2018).

\section{What are the Consequences of Illicit Trade?}

The negative consequences of illicit trade are widespread and damage a multitude of economic, socioeconomic and environmental outcomes. Shelley (2018) states that the illicit economy is threatening the future of the planet by destroying the quality of the air, sea, soil and land. Human life is threatened not only through the atrocities of human trafficking, but also by illicit trade which facilitates drug addiction and provides harmful counterfeit medications and agricultural products that hinder food security and health (Shelley, 2018). As Mashiri and Sebele-Mpofu (2015, pg. 41) state, illicit trade has 'enormous costs' that include the destabilisation of society, which not only endangers the environment, human life and wildlife, but also harms economies at all levels. Specifically, Mashiri and Sebele-Mpofu (2015) describe how illicit trade distorts local economies, reduces productivity and diverts resources from the legitimate to the illegitimate economy. Considering the global illicit cigarette trade alone, Joossens et al. (2010) state that eliminating this trade would save millions from premature death and recover billions 
in government revenue. Mashiri and Sebele-Mpofu (2015, pg. 42) describe the four major costs of illicit trade as '...lost revenue, distortion of market prices, collapse of local industries leading to unemployment and the social costs that endanger the health and safety of nationals, destroy vital habitats and ecosystems and threaten the tourism industry'. Thus, it is logical to assume that, given the extent of damage illicit trade inflicts on economic, environmental and socio-economic outcomes, establishing strong counter measures to combat illicit trade would be a priority for policymakers.

\section{Illicit Trade and Culture}

The EIU (2018, pg. 8) states that the GITE data measures economies on their structural capacity to protect against illicit trade and is based on the '...laws, regulations, systems and effectiveness of governance that contribute to the political and regulatory environment that indicates an economy's potential to combat illicit trade of different kinds'. The GITE data reveal that the illicit trade environment varies significantly across countries, with some dedicating substantial resources to prevent illicit transactions while other economies seemingly placing a lower value on thwarting the transactions. Thus, there appears to be differences in the political will needed to establish the policies and protection measures necessary to combat illicit trade across countries. In reference to the illicit trade of stolen material from archaeological sites, Brodie (2003) states that the simple answer as to why the trade exists is the lack of political will to prevent such transactions from occurring. What then drives the political will to dedicate resources and implement policies to counter illicit trade?

It is argued that in order to obtain political will to counter illicit trade, the 'issue' of illicit trade must first be created and 'issue creation' is cultural (Post et al., 2008; Burstein, 1999). As Burstein (1991) describes, an issue must be first defined as a problem before it can become a public issue. As an example, Burstein (1999) notes that environmental pollution and child abuse were not always considered public issues, and states that the process of issue creation is cultural. In the context of political culture and political preferences, Laitin and Wildavsky (1988) state that culture instills points of concern. Concerning social policy, Van Oorschot (2007, pg. 129) describes culture '... as consisting of the values, norms, and beliefs of welfare state actors', which Baldock (1999) states is a key variable in understanding social policy. Political behaviour, as Berman (2001) describes, is an outcome of an actor's motivations, interest and preferences, all of which are influenced by culture. In Steinberg (1984), Douglas and Wildavsky argue that environmental movements have directly shaped American political culture and Lantis (2002) describes an emerging consensus in the literature that culture significantly affects national security policy in terms of grand strategy and state behaviour.

Given this backdrop, the primary objective of this study is to explore the underlying relationship between countries' illicit trade environment and culture. If culture influences political issues, which can then garner the political will to confront and subsequently result in policy implementation, it is logical to conclude that cultural values and attitudes towards illegal trade will influence the political will to counter the trade and ultimately the country's illicit trade environment. This hypothesis is empirically tested using cross-country data from 62 countries from the new GITE data in addition to Hofstede's cultural dimensions. A description of the data and the specific hypothesis follows.

\section{Illicit Trade}

The GITE index is based on four categories: government policy, supply and demand, transparency and trade and the customs environment. The government policy category is designed to capture the extent to which countries have comprehensive anti-illicit trade laws and considers factors such as the extent of corruption among public officials, intellectual property protection and commitment to illicit traderelated treaties, cyber security and money laundering laws among other factors (EIU, 2018). The transparency and trade category measures the degree to which a government makes itself publicly accountable in anti-illicit trade efforts and considers factors such as its ability to track and trace consignments, governance in free trade zones, the extent to which the government reports on anti-human trafficking, intellectual property infringement and drug trafficking efforts, among other factors (EIU, 2018). The supply and demand category captures the institutional and economic variables that can facilitate or hinder illicit trade flows and includes factors such as labour market regulations, measures of organised crime, tax and security burdens and the quality of state institutions (EIU, 2018). Finally, the customs environment category measures a country's effectiveness in managing trade facilitation 
while preventing illicit trade and considers factors such as the percentage of shipments physically inspected, the number of hours for customs clearance and inspection, among other assessment measures. The GITE is a weighted average of these four categories and is normalised on a scale of 0-100 with higher scores reflecting environments that more strongly restrict illicit trade.

In sum, the GITE captures the ease of conducting illicit trade across countries. In the context of this study, it captures the end result of political efforts across countries to fight illicit trade, a process that begins with the creation of illicit trade as an issue that garners political will and leads to anti-illicit trade policies. As the GITE data indicate, the result differs significantly across countries. Finland, the United Kingdom and the United States received the highest GITE scores of 85.6, 85.1 and 82.5, respectively, and represent environments in which illicit trade is most difficult to conduct. Greece, South Africa, Columbia and China are in the middle of the spectrum with GITE scores of 61.7, 61.7, 61.6 and 60.9, respectively. Iraq and Libya received the two lowest scores of 14.4 and 8.6, respectively, and represent environments in which there is relative ease of conducting illicit trade. The wide range of scores suggest, at least in part, varying degrees of political will to combat the trade. It can be argued that these differences in political will are, at least in part, due to differences in cultural attitudes towards illicit trade.

\section{Culture}

Hofstede (2011, pg. 3) defines culture as the '...collective programming of the mind that distinguishes the members of one group or category of people from others'. From 1967 to 1973, Hofstede (1980) collected survey data on work-related values from over 117,000 IBM employees working in 40 different countries. Using this data, Hofstede (1980) originally identified four statistically distinct cultural dimensions which he labelled as 'power distance', 'individualism', 'masculinity' and 'uncertainty avoidance'. He later extended his work to include approximately 70 countries and two additional cultural dimensions of 'long-term orientation' and 'self-restraint' (Hofstede et al., 2010).

Hofstede's (2011) six dimensions of national culture are used to measure the culture within a country. Nonetheless, it is important to note that any quantitative measure of culture, which is qualitative in nature, cannot be expected to precisely capture all cultural nuances and Hofstede's cultural dimensions have been criticised in the literature (Steenkamp, 2001; Schwartz, 1994; Brett and Okumura, 1998). However, Drogendijk and Slangen (2006) find that over time, Hofstede's cultural dimensions have been validated in studies such as Van Oudenhoven (2001) and Søndergaard (1994).

\section{Power Distance}

Hofstede (2010) defines the power distance dimension as the degree to which the less-powerful members of a society accept that the power in society is unequally distributed, and notes that the underlying issue of this cultural dimension is how a society handles inequalities among people. Hofstede (n.d.) describes that in societies with a high degree of power distance, people accept a hierarchical order in which everybody has a place and no further justification for this order is needed. Alternatively, in a low power distance society, people strive for an equal distribution of power and demand justification when power inequalities are identified (Hofstede, n.d.).

Husted (2000) states that high power distance societies are more susceptible to paternalism, a system in which those in higher ranking positions give favours to subordinates in exchange for their loyalty. Seleim and Bontis (2009) extend this assessment and state that in high power distance societies, there is an expectation that subordinates will be obedient to their superiors. As Husted (2000) discusses, when there is a high degree of power distance within a society, decision-making is not based on merit, rather it is based on a balance of favours and loyalty structure. These studies suggest that corruption is not only more likely to be found in high power distance societies, but is also more likely to be accepted as a means of decision-making and doing business. Getz and Volkema (2001) argue this relationship between power distance and corruption and describe how officials in high power distance societies are more likely to demand or accept bribes given their higher rank in society. Yeganeh (2014) offers empirical evidence of the relationship and concludes that, after controlling for socio-economic development, Hofstede's higher power distance is significantly correlated with greater levels of perceived corruption. Further, studies conducted by Park (2003) and Davis and Ruhe (2003) lend additional support for the positive relationship between high power distance and higher levels of 
corruption. Corruption plays a significant role in illicit trade and is included in the GITE index (EIU, 2018). Bribery is used to smuggle illegal drugs, weapons, trafficked persons and stolen goods, among many other illicit goods, through customs inspections. Kickbacks and bribery are employed, so that officials will not report overfishing and overhunting of wildlife, overharvesting of timber or the illegal dumping of waste.

In sum, in high power distance societies, corruption tends to be more prevalent, the less-powerful members of society do not challenge inequities and decision-making is not based on merit. Thus, it is logical to assume that compared to a low power distance society, it is considerably less likely that a high power distance society will define illicit trade as a societal issue and garner the political will to affect change. The first hypothesis is thus stated:

H1: The greater the country's power distance, the lower its structural capacity to protect against illicit trade.

\section{Individualism}

Hofstede (2010) describes the individualistic societies as preferring loose ties between individuals and social networks. In individualistic societies, people are expected to take care of themselves and family, but not beyond their immediate family (Hofstede, n.d.). Hofstede refers to the opposite end of the spectrum as collectivism and states that collectivist societies prefer a tightly knit societal framework in which individuals are integrated into strong, cohesive groups that are expected to protect group members in exchange for unquestioning loyalty (Hofstede, 2010; Hofstede, n.d.). As Tavakoli et al. (2003) discuss, individualism can be described as an employee's independence from the organisation and in individualistic societies, individual achievements are prioritised rather than group achievements.

In a study comparing Taiwanese and American auditing students, Brody et al. (1999) find that Taiwanese auditing students, who are more collectivist, are less likely to whistleblow than American auditing students, who are more individualistic. Brody et al. (1999) argue that the difference in the willingness to whistleblow stems from difference in the perceived importance of 'saving face'. As Brody et al. (1999) describe, Taiwanese place a greater value of protecting ingroup members than Americans and are comparatively less likely to whistleblow and expose a problem with their workgroup. In a crosscountry study, Armstrong (1996) offers empirical evidence that more individualistic cultures perceive ethical problems as having greater relative importance than collectivist cultures. Further, Seleim and Bontis (2009) discuss that in highly collective societies, individuals are more willing to break rules and legal procedures to protect and assist ingroup members. This finding is supported by Banuri and Eckel (2012) who state that collectivist societies are more susceptible to corruption as individuals are more likely to break laws that contradict group moral codes, and by Getz and Volkema (2001) who note that public officials are more likely to demand or accept a bribe as the bribe can be used to support the official's ingroup.

In sum, in collectivist societies, whistleblowing is less likely to occur, ethical problems have a lesser weight and corruption tends to be more prevalent. Thus, it is reasonable to assume that compared to an individualistic society, it is considerably less likely that a collectivist society will define illicit trade as a societal issue and garner the political will to affect change. The second hypothesis is thus stated:

H2: The more collectivist the country, the lower its structural capacity to protect against illicit trade.

\section{Masculinity}

Hofstede (n.d.) describes masculine societies as being competitive and having a preference for achievement, heroism and assertiveness. On the other end of spectrum, Hofstede (n.d.) states that feminine societies are consensus oriented and place a strong preference for cooperation, modesty, caring for the weak and quality of life. Banuri and Eckel (2012) state that corruption is more prevalent in masculine societies as material success is valued over the quality of life, and Getz and Volkema (2001) note that because more value is placed on material achievement than the means by which it was obtained, the ends can justify the means in masculine societies. Further, Yeganeh (2014) offers empirical evidence that, after controlling for socio-economic development, masculinity is significantly correlated with greater levels of perceived corruption. In a study of consumer ethics, Swaidan (2012) finds that consumers who score low on masculinity are more likely to reject questionable activities than consumers 
who score relatively high on masculinity. In a study comparing Taiwanese and American sales agents, Blodgett et al. (2001) find that masculine individuals are less sensitive to the interest of one's company, customers, competitors and colleagues than feminine individuals.

In sum, masculine societies place a lower value on the quality of life and care of others. Previous research has associated masculine societies with greater corruption and as having individuals who are less likely to reject questionable activities and be sensitive to the interests of others. It is, therefore, logical to assume that compared to a feminine society, it is considerably less likely that a masculine society will define illicit trade as a societal issue and garner the political will to affect change. The third hypothesis is thus stated:

\section{H3: The more masculine the country, the lower its structural capacity to protect against illicit trade.}

\section{Uncertainty Avoidance}

Hofstede et al. (2010) describe uncertainty avoidance as the degree to which members feel uncomfortable with uncertainty and ambiguity. Hofstede (n.d.) states that the underlying piece of the uncertainty avoidance dimension is how society addresses the fact that the future cannot be known. Is it best to try to control the future or just let the future unfold? Countries with high uncertainty avoidance tend to have rigid codes of beliefs and behaviour (Hofstede et al., 2010). Chase (1997) notes that the desire to avoid uncertainty leads to a strong structuring of activities and processes. In a cross-country study, Armstrong (1996) offers empirical evidence that cultures with higher levels of uncertainty avoidance perceive ethical problems as having greater relative importance than cultures with low uncertainty avoidance. In reference to corporate takeover decisions, Frijns et al. (2013) offer empirical evidence that uncertainty avoidance plays a significant role in relatively large takeovers, and that CEOs from high uncertainty avoiding countries are less likely to engage in cross-border or cross-industry takeovers.

In sum, there is a desire to control the future and reduce ambiguity in high uncertainty avoidance societies. These societies attempt to control the future by establishing a structure that is grounded in rigid codes of beliefs and behaviour, and previous research has found that high uncertainty avoidance is associated with less risk-taking behaviour and higher ethical standards. It is, therefore, reasonable to assume that compared to a high uncertainty avoidance society, it is less likely that a low uncertainty avoidance society will define illicit trade as a societal issue and garner the political will to affect change. The fourth hypothesis is thus stated:

H4: The less uncertainty avoidance within a country, the lower its structural capacity to protect against illicit trade.

\section{Long-term Orientation}

Hofstede (n.d.) defines societies with a long-term orientation as those that encourage thrift and education as means for preparation for the future. Payne et al. (2016) describe societies with long-term orientation as those that encourage values towards future rewards such as perseverance and thrift, and Buck et al. (2010, pg. 224) note that long-term orientation ' ... is arguably the most important cultural dimension through its strong association with a nation's propensity to save (and) invest...'. Alternatively, societies with short-term orientation maintain time-honoured traditions and norms (Hofstede, n.d.). Payne et al. (2016) describe short-term orientation societies as those which foster values associated with a respect for tradition, saving face and fulfilling society expectations. In a review of accounting literature, Khlif (2016) concludes that long-term orientation has been positively associated with social environmental disclosure and Park and Lemaire (2011) find that long-term orientation has a strong positive influence on life insurance demand.

Thus, societies with long-term orientation have values associated with future rewards and encourage preparation for the future through education, investment and saving. On the other hand, societies with short-term orientation foster respect for tradition, including saving face and fulfilling society expectations. The focus on the preparation for the future through saving and investment in long-term orientation societies suggests that it is more likely that these societies will define illicit trade as a societal issue and garner the political will to affect change as illicit trade has severe negative effects on the future. The fifth hypothesis is thus stated: 
H5: The greater the short-term orientation within a country, the lower its structural capacity to protect against illicit trade.

\section{Indulgence}

Hofstede's final cultural dimension is indulgence versus restraint. Hofstede (n.d.) defines indulgent societies as those allowing for relatively free gratification of basic and natural and human desires such as enjoying life and having fun. Alternatively, societies that value restraint are typically governed by strict social norms which discourage gratification of needs (Hofstede, n.d.). As Kraman et al. (2018, pg. 28) describe, indulgent societies have '.... a culture willing to fall into a pit of impulses and desires'. In an empirical analysis of national culture and carbon dioxide emissions and economic growth, Disli et al. (2016) find that a higher level of indulgence in a country will shift its carbon dioxide Environmental Kuznets Curve upwards. Disli et al. (2016, pg. 421) note that the indulgence cultural dimension has not been widely tested, but '.. it is expected that indulgent societies are characterized by a more wasteful and extravagant lifestyle...'. It is, therefore, logical to assume that societies that are more likely to give into impulses to gratify present desires are less likely than a restrained society to define illicit trade as a societal issue and garner the political will to affect change. The sixth hypothesis is thus stated:

H6: The less restrained a country, the lower its structural capacity to protect against illicit trade.

\section{Research methodology}

The above six hypotheses are tested using regression analysis. A list of countries included in this study is presented in Table 1.

Table 1: Countries Included in Analysis

\begin{tabular}{|l|l|l|l|l|}
\hline Algeria & Denmark & Japan & Philippines & South Korea \\
Argentina & Estonia & Latvia & Poland & Spain \\
Australia & Finland & Lithuania & Portugal & Sweden \\
Austria & France & Luxembourg & Romania & Taiwan \\
Belgium & Germany & Malaysia & Russia & Thailand \\
Brazil & Greece & Malta & Saudi Arabia & Trinidad and Tobago \\
Bulgaria & Hong Kong & Mexico & Serbia & Tunisia \\
Canada & Hungary & Morocco & Singapore & Turkey \\
Chile & India & Netherlands & Slovakia & United Arab Emirates \\
China & Indonesia & New Zealand & Slovenia & United Kingdom \\
Colombia & Ireland & Pakistan & South Africa & United States \\
Croatia & Italy & Peru & & Uruguay \\
Czech Republic & & & & Venezuela \\
& & & Vietnam \\
\hline
\end{tabular}

For proper model specification, the following control variables are included in the analysis.

\section{Control Variables}

A country's ability to build the necessary infrastructure to protect against illicit trade will largely depend on its level of economic development. While a country can develop the political will to address illicit trade, it will not be able to effectively counter the transactions without extensive resources. Further, greater economic development is associated with lower levels of corruption (Ata and Arvas, 2011). The level of economic development is controlled for using the GDP per person, which is available from the World Bank. 
The degree of economic freedom enjoyed is also controlled for in this analysis. Economically free countries have governments that allow economic, business and financial transactions to transpire with less regulation and restriction and corruption is not needed to facilitate transactions. Alternatively, countries with little economic freedom are more likely to observe rent-seeking behaviours (DiRienzo, 2019; Ata and Arvas, 2011). The Heritage Foundation (2016) describes economic freedom as a measure of the overall health of a country, as it is strongly correlated with a multitude of economic and social development factors. The level of economic freedom enjoyed by a country is controlled for in this analysis using the Heritage Foundation's Economic Freedom Index.

A total of 62 countries have data measures for the above cultural and control variables. Table 2 provides a summary and the descriptive statistics of the data used in this analysis.

Table 2: Data Summary and Descriptive Statistics

\begin{tabular}{|c|c|c|c|c|c|c|}
\hline Variable & Data Source & Mean & St. Dev. & Min. & Max. & $n$ \\
\hline $\begin{array}{ll}\text { Illicit } & \text { trade } \\
\text { environment } & \end{array}$ & $\begin{array}{l}2018 \text { Global Illicit Trade Environment } \\
\text { (GITE) }\end{array}$ & 65.8 & 12.54 & 28.1 & 85.6 & 62 \\
\hline $\begin{array}{l}\text { Economic } \\
\text { development }\end{array}$ & $\begin{array}{l}2017 \text { GDPPC, World Bank } \\
\text { (GDPPC) }\end{array}$ & $25,871.40$ & $21,597.78$ & 1155.4 & $109,453.0$ & 62 \\
\hline Economic freedom & $\begin{array}{l}2017 \text { Economic Freedom Index, Heritage } \\
\text { Foundation } \\
(\mathrm{EFI})\end{array}$ & 67.2 & 10.68 & 27.0 & 89.8 & 62 \\
\hline Power distance & $\begin{array}{l}\text { Hofstede's Power Distance } \\
\text { (PDI) }\end{array}$ & 60.2 & 20.59 & 11.0 & 104.0 & 62 \\
\hline Individualism & $\begin{array}{l}\text { Hofstede's Individualism } \\
\text { (IDV) }\end{array}$ & 45.8 & 23.04 & 12.0 & 91.0 & 62 \\
\hline Masculinity & $\begin{array}{l}\text { Hofstede's Masculinity } \\
\text { (MAS) }\end{array}$ & 50.1 & 19.42 & 5.0 & 110.0 & 62 \\
\hline $\begin{array}{l}\text { Uncertainty } \\
\text { avoidance }\end{array}$ & $\begin{array}{l}\text { Hofstede's Uncertainty Avoidance } \\
\text { (UAI) }\end{array}$ & 67.0 & 22.82 & 8.0 & 112.0 & 62 \\
\hline $\begin{array}{l}\text { Long-term } \\
\text { orientation }\end{array}$ & $\begin{array}{l}\text { Hofstede's Long-term Orientation } \\
\text { (LTO) }\end{array}$ & 49.0 & 22.66 & 12.6 & 100.0 & 62 \\
\hline Indulgence & $\begin{array}{l}\text { Hofstede's Indulgence } \\
\text { (IND) }\end{array}$ & 46.6 & 21.57 & 0 & 100.0 & 62 \\
\hline
\end{tabular}

Models

Regression analysis is used to test the above hypotheses using GITE index as the dependent variable. Model 1 is the baseline model that establishes the expected coefficient signs and significance of the control variables, economic development $(G D P P C)$ and economic freedom (EFI).

$$
G I T E=\beta_{0}+\beta_{1} G D P P C+\beta_{2} E F I+\varepsilon
$$

Model 2 adds the culture variables to the baseline model. The cultural variables are denoted as follows: power distance $(P D I)$, individualism $(I D V)$, masculinity $(M A S)$, uncertainty avoidance $(U A I)$, long-term orientation $(L T O)$ and indulgence $(I N D)$. 
Recalling that higher values of GITE reflect countries that have a greater structural capacity to protect against illicit trade, the above-stated hypotheses indicate that $\beta_{3}$ is expected to be negative, $\beta_{4}$ is expected to be positive, $\beta_{5}$ is expected to be negative, $\beta_{6}$ is expected to be positive, $\beta_{7}$ is expected to be positive and $\beta_{8}$ is expected to be negative, in addition to the positive coefficients on both control variables.

\section{Results}

Table 3 provides the estimated regression results for models 1 and 2 .

Table 3: Regression Results (Dependent Variable GITE)

\begin{tabular}{|c|c|c|}
\hline & Model 1 & Model 2 \\
\hline $\begin{array}{l}\text { Intercept } \\
\text { coefficient estimate } \\
\text { Standard deviation } \\
p \text {-Value }\end{array}$ & $\begin{array}{l}13.11 * \\
7.37 \\
0.0791 \\
\end{array}$ & $\begin{array}{l}7.08 \\
9.36 \\
0.4532 \\
\end{array}$ \\
\hline $\begin{array}{l}G D P P C \\
\text { Coefficient estimate } \\
\text { Standard deviation } \\
p \text {-Value } \\
\end{array}$ & $\begin{array}{l}0.00039 * * * \\
0.0000592 \\
<0.0001\end{array}$ & $\begin{array}{l}0.00013 * * \\
0.000053 \\
0.0179\end{array}$ \\
\hline $\begin{array}{l}E F I \\
\text { Coefficient estimate } \\
\text { Standard deviation } \\
p \text {-Value }\end{array}$ & $\begin{array}{l}0.597 * * * \\
0.122 \\
<0.0001 \\
\end{array}$ & $\begin{array}{l}0.552 * * * \\
0.091 \\
<0.0001\end{array}$ \\
\hline $\begin{array}{l}\text { PDI } \\
\text { Coefficient estimate } \\
\text { Standard deviation } \\
p \text {-Value }\end{array}$ & & $\begin{array}{l}-0.032 \\
0.052 \\
0.5381 \\
\end{array}$ \\
\hline $\begin{array}{l}I D V \\
\text { Coefficient estimate } \\
\text { Standard deviation } \\
p \text {-Value }\end{array}$ & & $\begin{array}{l}0.181 * * * \\
0.0443 \\
0.0001\end{array}$ \\
\hline $\begin{array}{l}\text { MAS } \\
\text { Coefficient estimate } \\
\text { Standard deviation } \\
p \text {-Value }\end{array}$ & & $\begin{array}{l}-0.011 \\
0.040 \\
0.7685 \\
\end{array}$ \\
\hline $\begin{array}{l}\text { UAI } \\
\text { Coefficient estimate } \\
\text { Standard deviation } \\
p \text {-Value }\end{array}$ & & $\begin{array}{l}0.081 * * \\
0.0345 \\
0.0228 \\
\end{array}$ \\
\hline $\begin{array}{l}\text { LTO } \\
\text { Coefficient estimate } \\
\text { Standard deviation } \\
p \text {-Value }\end{array}$ & & $\begin{array}{l}0.097 * * \\
0.0407 \\
0.0212 \\
\end{array}$ \\
\hline $\begin{array}{l}\text { IND } \\
\text { Coefficient estimate } \\
\text { Standard deviation } \\
p \text {-Value }\end{array}$ & & $\begin{array}{l}0.050 \\
0.0460 \\
0.2864\end{array}$ \\
\hline $\begin{array}{l}R_{a}^{2} \\
F \\
N\end{array}$ & $\begin{array}{l}0.6667 \\
82.0 * * * \\
82\end{array}$ & $\begin{array}{l}0.7912 \\
29.90 * * * \\
62\end{array}$ \\
\hline
\end{tabular}

Note: *Significant at $90 \%$ confidence; **significant at $95 \%$ confidence; $* * *$ significant at $99 \%$ confidence.

As shown in Table 3, the analysis results indicate that there is empirical support for $H 2, H 4$ and $H 5$ in addition to the expected signs on the control variables. Culturally more individualistic countries have a greater uncertainty avoidance and a stronger long-term orientation, as well as a stronger structural capacity to protect against illicit trade on average. Although not statistically significant, $\beta_{3}$ and $\beta_{5}$ have the expected negative sign, indicating that countries that are more masculine with greater power distance have a lower structural capacity to protect against illicit trade. An F-test comparing Model 1 to Model 
2 indicates that the cultural variables add statistically significant explanatory power. Overall, the analysis results lend support to overarching argument that culture affects the relative importance a society places on the issue of illicit trade and the political will to counter the transactions.

\section{Conclusions}

Illicit economy is threatening the future of the planet (Shelly, 2018). The trade harms the environment, human and wildlife and slows economic development, and is estimated to account for up to $15 \%$ of the world's GDP (Shelly, 2018; Mashiri \& Sebele-Mpofu, 2015). It is imperative that policymakers continue to combat these illicit transactions; however, it is argued here that policymakers - especially those working in the global arena - need to be mindful of the impact that culture has on a country's attitude towards illicit trade. Pre-existing cultural mindsets often play a key role in influencing a country's political will and desire to address matters such as illicit trade and acknowledge its widespread harmful impact.

In sum, anti-illicit policy initiatives are likely to be more challenging in collectivist countries with lower uncertainty avoidance and a short-term orientation. Policymakers need to tailor their anti-illicit trade efforts in these countries. It needs to be recognised that these societies will not likely place the same value on countering illicit trade as the countries that are culturally more individualistic, have greater uncertainty avoidance and have a strong long-term orientation. It can be argued that the relative importance of illicit trade as a problem clearly differs across countries, and that these differences are based on differences in culture. Countering illicit trade requires a global commitment and in order to garner this commitment, each society must perceive illicit trade as an issue -it is a basic societal problem that needs to be addressed. As widespread global efforts are made to counter illicit trade, the results of this study suggest that there is an increased need to be cognizant of the role of culture in anti-illicit trade efforts before implementing a one-size-fits-all methodology to mitigate the presence and spread of illicit trade across countries.

\section{References}

Armstrong, R. W. (1996). The relationship between culture and perception of ethical problems in international marketing. Journal of Business Ethics, 15(11), 1199-1208.

Ata, A. Y., \& Arvas, M. A. (2011). Determinants of economic corruption: a cross-country data analysis. International Journal of Business and Social Science, 2(13), 161-169.

Basu, G. (2014). Concealment, corruption, and evasion: A transaction cost and case analysis of illicit supply chain activity. Journal of Transportation Security, 7(3), 209-226.

Baldock, J. (1999). Culture: the missing variable in understanding social policy?. Social Policy \& Administration, 33(4), 458-473.

Blodgett, J. G., Lu, L. C., Rose, G. M., \& Vitell, S. J. (2001). Ethical sensitivity to stakeholder interests: A crosscultural comparison. Journal of the Academy of Marketing Science, 29(2), 190-202.

Brett, J. M. and Okumura, T. (1998), “Inter- and intracultural negotiation: US and Japanese negotiators”, Academy of Management Journal, Vol. 41, No. 5, pp. 495-510.

Brodie, N. (2003). Stolen history: looting and illicit trade. Museum International, 55(3-4), 10-22.

Brody, R. G., Coulter, J. M., \& Lin, S. (1999). The effect of national culture on whistle-blowing perceptions. Teaching Business Ethics, 3(4), 383-398.

Buck, T., Liu, X., \& Ott, U. (2010). Long-term orientation and international joint venture strategies in modern China. International Business Review, 19(3), 223-234.

Burstein, P. (1991). Policy domains: Organization, culture, and policy outcomes. Annual Review of Sociology, 17(1), 327-350.

Chase, O. G. (1997). Legal processes and national culture. Cardozo J. Int'l \& Comp. L., 5, 1.

Davis, J. H., \& Ruhe, J. A. (2003). Perceptions of country corruption: Antecedents and outcomes. Journal of Business Ethics, 43(4), 275-288. 
DiRienzo, C. E. (2019). Culture, corruption, and women in government. International Journal of Cross Cultural Management, 19(3), 315-332.

Disli, M., Ng, A., \& Askari, H. (2016). Culture, income, and CO2 emission. Renewable and Sustainable Energy Reviews, 62, 418-428.

Drogendijk, R. and Slangen, A. (2006), "Hofstede, Schwartz, or managerial perceptions? The effects of different cultural distance measures on establishment mode choices by multinational enterprises", International Business Review, Vol. 15, pp. $361-380$.

Fisman, R., \& Wei, S. J. (2009). The smuggling of art, and the art of smuggling: Uncovering the illicit trade in cultural property and antiques. American Economic Journal: Applied Economics, 1(3), 82-96.

Frijns, B., Gilbert, A., Lehnert, T., \& Tourani-Rad, A. (2013). Uncertainty avoidance, risk tolerance and corporate takeover decisions. Journal of Banking \& Finance, 37(7), 2457-2471.

Getz, K.A. and Volkema, R.J. (2001). Culture, Perceived Corruption and Economics. Business \& Society, 40(1): $7-30$.

Heritage Foundation. (2016). 2016 Index of Economic Freedom. Accessed July 24, 2020, https://www.heritage.org/index/pdf/2016/book/index_2016.pdf.

Hofstede (n.d.) Hofstede Insights. Accessed July 22, 2020 https://hi.hofstede-insights.com/national-culture.

Hofstede, G. (1980), Culture's Consequences: International Differences in Work-related Values. Beverly Hills, CA: Sage.

Hofstede, G., Hofstede, G.J., and Minkov, M. (2010). Cultures and Organizations: Software of the Mind: Intercultural Cooperation and Its Importance for Survival. USA: McGraw-Hill.

Hofstede, G. (2011). Dimensionalizing cultures: The Hofstede model in context. Online readings in psychology and culture, 2(1), 2307-0919.

Husted, B.W. (2000). “The Impact of National Culture on Software Piracy,” Journal of Business Ethics, Vol. 26; pp. 197-211.

Joossens, L., Merriman, D., Ross, H., \& Raw, M. (2010). The impact of eliminating the global illicit cigarette trade on health and revenue. Addiction, 105(9), 1640-1649.

Kraman, S., Huling, A. M., Qin, S., Zhang, W., Jiang, A., Xu, J. \& Mathew, M. (2018). Hofstede’s cultural dimensions \& ethics among accountants in the USA and China. Copyright 2018 by Institute for Global Business Research, Nashville, TN, USA, 275.

Khlif, H. (2016). Hofstede's cultural dimensions in accounting research: a review. Meditari Accountancy Research.

Laitin, D. D., \& Wildavsky, A. (1988). Political culture and political preferences. The American Political Science Review, 589-597.

Lantis, J. S. (2002). Strategic culture and national security policy. International studies review, 4(3), 87-113.

Mashiri, E., \& Sebele-Mpofu, F. Y. (2015). Illicit trade, economic growth and the role of Customs: a literature review. World Customs Journal, 9(2), 38-50.

OECD (2016). Illicit Trade: Converging Criminal Networks, OECD Reviews of Risk Management Policies, OECD Publishing, Paris. http://dx.doi.org/10.1787/9789264251847-en.

Park, H. (2003). Determinants of corruption: A cross-national analysis. Multinational Business Review.

Park, S., \& Lemaire, J. (2011). Culture matters: Long-term orientation and the demand for life insurance. AsiaPacific Journal of Risk and Insurance, 5(2).

Payne, D., Corey, C. M., \& Fok, L. Y. (2016). The indirect effects of cultural values on ethical decision making via utilitarian ethical orientation. American Journal of Management, 16(1).

Post, L. A., Salmon, C. T., \& Raile, A. N. (2008). Using public will to secure political will. REFORM, 113.

Schwartz, S. H. (1994), "Beyond individualism/collectivism: New cultural dimensions of values”, in U. Kim, H. C. Triandis, C. Kagitcibasi, S. C. Choi, and G. Yoon (Eds.), Individualism and collectivism: Theory, methods, and applications, Thousand Oaks, Sage Publications, pp. 85-119. 
Seleim, A. and Bontis, N. (2009). The relationship between culture and corruption: A cross-national study. Journal of Intellectual Capital, 10(1), 165 - 184.

Shelley, Louise, I. (2018) Dark Commerce. Princeton University Press, Princeton, New Jersey.

Simmers, C. S., \& Schaefer, A. D. (2015). Counterfeit luxury goods purchase motivation: A cultural comparison. Journal of International Business and Cultural Studies Volume 9.

Søndergaard, M. (1994). Hofstede’s consequences: A study of reviews, citations and replications”, Organization Studies, 15(3), 447-456.

Staake, T., Thiesse, F., \& Fleisch, E. (2009). The emergence of counterfeit trade: a literature review. European Journal of Marketing, 43(3/4), 320 - 349

Steenkamp, J.B.E.M. (2001). The role of national culture in international marketing research. International Marketing Review, 18(1), 30-44.

Steinberg, G. (1984). Mary Douglas and Aaron Wildavsky, Risk and Culture: An Essay on the Selection of Technical and Environmental Dangers (Berkeley and London: Univ. of California Press, 1982,£ 11.25). Pp. 222. Journal of American Studies, 18(1), 145-146.

Stumpf, S.A. and Chaudhry, P. (2010). Country matters: Executives weigh in on the causes and counter measures of counterfeit trade. Business Horizons, (53), 305 - 314

Swaidan, Z. (2012). Culture and consumer ethics. Journal of Business Ethics, 108(2), 201-213.

Tavakoli, A. A., Keenan, J. P., \& Cranjak-Karanovic, B. (2003). Culture and whistleblowing an empirical study of Croatian and United States managers utilizing Hofstede's cultural dimensions. Journal of Business Ethics, 43(12), 49-64.

The Economist Intelligence Unit (2018). The Global Illicit Trade Environment Index. Accessed June 12, 2020, http://illicittradeindex.eiu.com/documents/EIU\%20Global\%20Illicit\%20Trade\%20Environment\%20Index\%202 018\%20-\%20Overall\%20Results\%20White\%20Paper\%20June\%206\%20FINAL.pdf.

Van Oorschot, W. (2007). Culture and social policy: a developing field of study. International Journal of Social Welfare, 16(2), 129-139.

Van Oudenhoven, J. P. (2001), "Do organizations reflect national cultures? A 10-nation study”, Internal Journal of Intercultural Relations, 25, 89-107.

World Health Organization. (2003). World Health Assembly Resolution 56.1. Accessed July 13, 2020 https://www.who.int/tobacco/framework/final_text/en/index3.html.

Yeganeh, H. (2014). Culture and corruption. International Journal of Development Issues. 